\title{
EFFECT OF A CARBONIC ANHYDRASE INHIBITOR (DIAMOX) ON INTRA-OCULAR PRESSURE OF RABBITS AND CATS*
}

\author{
BY \\ J. GLOSTER AND E. S. PERKINS \\ Institute of Ophthalmology, University of London \\ Director of Research, Sir Stewart Duke-Elder
}

THE observation by Becker (1954) that the oral administration of a carbonic anhydrase inhibitor, 2-acetylamino-1, 3, 4-ihiadiazole-5-sulphonamide (Diamox, Lederle), causes a reduction of ocular tension in many glaucoma patients has been fully confirmed by other investigators (Grant and Trotter, 1954; Breinin and Gortz, 1954; Kleinert, 1954; Perkins, 1955). The efficacy of this drug is independent of the aetiology of the glaucomatous condition, a fact which suggests that it interferes with a basic mechanism concerned with the maintenance of intra-ocular pressure, and which has prompted investigations of its action on the intra-ocular pressure in normal animals. Grant and Trotter (1954) stated that intravenous injection of the sodium salt of Diamox reduced the intra-ocular pressure in normal rabbits, and Becker (1955) reported similar findings in rabbits and dogs. Becker estimated the intra-ocular pressure in conscious animals by tonometry, a procedure which has certain disadvantages, among these being the uncertainty of the absolute value of the intra-ocular pressures and the limitation of the number of readings which can be made in a given time; moreover, a simultaneous record of the blood pressure could not be obtained and this is essential since variations in blood pressure may have a significant effect on the intra-ocular pressure of experimental animals. These disadvantages can be overcome by obtaining continuous manometric records of the intraocular and blood pressure. Using such methods the following experiments were performed.

\section{(I) Effect of Intravenous Injection of Sodium Diamox on INTRa-Ocular Pressure in Rabitts}

\section{(a) Diamox (50 mg./kg.) Intravenously}

Method.-Rabbits, weighing $2 \cdot 5-4 \mathrm{~kg}$. were anaesthetized by the intravenous injection of a 25 per cent. solution of urethane in a dosage of $1.75 \mathrm{~g} . / \mathrm{kg}$. One femoral artery was cannulated to provide a blood pressure record and a cannula was inserted into a femoral vein through which intravenous injections could be made. Two drops of 1 per cent. pantocaine were instilled into both conjunctival sacs and No. 15 hypodermic needles were inserted into the anterior chambers; these were connected by means of polythene tubing to rubber membrane manometers of a type similar to those described by Davson and Purvis (1950), from which by means of an optical arrangement a continuous photographic record was obtained. The blood-pressure cannula was connected to a similar manometer.

The substance injected was the sodium salt of Diamox made up as a 5 per cent. solution. A total 2.5-4 ml. (according to the weight of the animal) was injected over $30 \mathrm{sec}$.

*Received for publication July 20, 1955. 
Results.-Altogether nineteen rabbits were investigated using a dosage of 50 mg./kg. The results are presented in Table I (opposite).

The primary aim of these experiments was to discover the effect of Diamox on the normai eye, and for this reason it was decided to eliminate results in which the following experimental conditions were not satisfied:

(i) The intra-ocular pressures should have remained steady or should not have risen by more than $2 \mathrm{~cm}$. $\mathrm{H}_{2} \mathrm{O}$ in the $10 \mathrm{~min}$. preceding injection of Diamox.

(ii) The initial intra-ocular pressures should be between 18 and $27 \mathrm{~cm} . \mathrm{H}_{2} 0$, these being regarded as the limits of the physiological range of intra-ocular pressures using this method of measurement.

(iii) Reduction of intra-ocular pressure should amount to $2 \mathrm{~cm} . \mathrm{H}_{2} \mathrm{O}$ at least, 15 min. after injection of Diamox, in order to be considered significant.

(iv) Blood pressure should not have fallen by more than $5 \mathrm{~mm}$. Hg $15 \mathrm{~min}$. after Diamox injection; this condition ensured that any reduction in intra-ocular pressure was not the reflection of a change in the blood pressure.

These criteria were fulfilled for thirteen rabbits for which results are given in Table I, although for three animals a satisfactory record of the intra-ocular pressure was obtained for one eye only. A significant fall in intra-ocular pressure was observed in eleven of the thirteen rabbits in this group. The reduction of pressure varied from animal to animal, but was usually $2-5 \mathrm{~cm} . \mathrm{H}_{2} \mathrm{O}$.

Immediately after the injection of Diamox, there was frequently a marked transitory fall in blood pressure, but the original level was rapidly regained. A rapid rise of intra-ocular pressure often occurred simultaneously, but this was also a transient effect and the pressure fell to its original level within 3 minutes, after which a slow reduction in intra-ocular pressure became evident. These immediate effects on the intra-ocular and blood pressures are illustrated in Figs 1 and 2 (overleaf).

The effect over a longer period of time is illustrated in Fig. 3 (overleaf). In this animal there was a small reduction of blood pressure immediately after injecting Diamox, but the initial rise in the intra-ocular pressures was very small. Before injecting Diamox both intra-ocular pressures were rising slowly, the right being $27 \mathrm{~cm} . \mathrm{H}_{2} \mathrm{O}$ and the left $24 \mathrm{~cm} . \mathrm{H}_{2} \mathrm{O} ; 10$ minutes later both had fallen to $20 \mathrm{~cm} . \mathrm{H}_{2} \mathrm{O}$ and this reduction continued slowly until, 30 minutes after giving Diamox, both intra-ocular pressures were $19 \mathrm{~cm} . \mathrm{H}_{2} \mathrm{O}$. This record illustrates well that the action of this substance is rapid, since a fall in intra-ocular pressure in this rabbit was evident 60-120 seconds after injecting Diamox.

It was not possible to determine the duration of the reduction of intra-ocular pressure because the blood pressure could not be maintained at a steady level for a sufficient time, but, in one rabbit, which maintained a fairly constant blood pressure for 2 hours, there was no certain indication that the intra-ocular pressures were recovering.

In the six rabbits in which the criteria of normality were not met, the intra-ocular pressures were falling in three eyes when Diamox was injected and in these eyes no effect was found. Two rabbits having high intra-ocular pressures when Diamox was administered are of interest since there was a marked reduction of pressure. For example, Fig. 4 (overleaf) shows that after Diamox was injected the right intra-ocular pressure fell from 48 to $23 \mathrm{~cm}$. $\mathrm{H}_{2} \mathrm{O}$ in fifteen min., while the left eye showed a fall of only $7 \mathrm{~cm} \mathrm{H}_{2} \mathrm{O}$ in the same time. 
TABLE I

\section{EFFECT OF INTRAVENOUS SODIUM DIAMOX $(50 \mathrm{mg} . / \mathrm{kg}$.) ON INTRA-OCULAR PRESSURE OF RABBITS}

\begin{tabular}{|c|c|c|c|}
\hline Rabbit & Eye & $\begin{array}{l}\text { Initial Intra-Ocular Pressure } \\
\left(\mathrm{cm} . \mathrm{H}_{2} \mathrm{O}\right)\end{array}$ & $\begin{array}{l}\text { Fall in Intra-Ocular Pressure } \\
\left(\mathrm{cm} . \mathrm{H}_{2} \mathrm{O}\right) \\
15 \text { min. after Diamox Injection }\end{array}$ \\
\hline 1 & $\begin{array}{l}\mathbf{R} \\
\mathbf{L}\end{array}$ & $\begin{array}{l}21 \text { steady } * \\
21 \text { steady }\end{array}$ & $\begin{array}{l}5 \\
4\end{array}$ \\
\hline 2 & $\begin{array}{l}\mathbf{R} \\
\mathbf{L}\end{array}$ & $\begin{array}{l}48 \text { rising } * \\
24 \text { steady }\end{array}$ & $\begin{array}{r}20 \\
5\end{array}$ \\
\hline 3 & $\begin{array}{l}\mathbf{R} \\
\mathbf{L}\end{array}$ & $\begin{array}{l}22 \text { steady } \\
22 \text { steady }\end{array}$ & $\begin{array}{l}2 \\
4\end{array}$ \\
\hline 4 & $\begin{array}{l}\mathbf{R} \\
\mathbf{L}\end{array}$ & $\begin{array}{l}39 \text { steady } \\
27 \text { steady }\end{array}$ & $\begin{array}{l}7 \\
4\end{array}$ \\
\hline 5 & $\begin{array}{l}\mathbf{R} \\
\mathbf{L}\end{array}$ & $\begin{array}{l}23 \text { steady } \\
22 \text { steady }\end{array}$ & $\begin{array}{l}2 \\
1\end{array}$ \\
\hline 6 & $\mathbf{R}$ & 18 falling * & 0 \\
\hline 7 & $\mathbf{R}$ & $\begin{array}{l}31 \text { rising } \\
30 \text { rising }\end{array}$ & $\begin{array}{l}2 \\
3\end{array}$ \\
\hline 8 & $\begin{array}{l}\mathbf{R} \\
\mathbf{L}\end{array}$ & $\begin{array}{l}52 \text { rising } \\
16 \text { falling }\end{array}$ & $\begin{array}{r}17 \\
0\end{array}$ \\
\hline 9 & $\begin{array}{l}\mathbf{R} \\
\mathbf{L}\end{array}$ & $\begin{array}{l}25 \text { steady } \\
25 \text { falling }\end{array}$ & $\begin{array}{l}4 \\
0\end{array}$ \\
\hline 10 & $\begin{array}{l}\mathbf{R} \\
\mathbf{L}\end{array}$ & $\begin{array}{l}22 \text { steady } \\
27 \text { steady }\end{array}$ & $\begin{array}{l}5 \\
5\end{array}$ \\
\hline 11 & $\begin{array}{l}\mathbf{R} \\
\mathbf{L}\end{array}$ & $\begin{array}{l}18 \text { steady } \\
21 \text { steady }\end{array}$ & $\begin{array}{l}2 \\
3\end{array}$ \\
\hline 12 & $\begin{array}{l}\mathbf{R} \\
\mathbf{L}\end{array}$ & $\begin{array}{l}18 \text { steady } \\
18 \text { steady }\end{array}$ & $\begin{array}{l}4 \\
3\end{array}$ \\
\hline 13 & $\begin{array}{l}\mathbf{R} \\
\mathbf{L}\end{array}$ & $\begin{array}{l}19 \text { steady } \\
23 \text { steady }\end{array}$ & $\begin{array}{l}2 \\
4\end{array}$ \\
\hline 14 & $\begin{array}{l}\mathbf{R} \\
\mathbf{L}\end{array}$ & $\begin{array}{l}21 \text { steady } \\
18 \text { steady }\end{array}$ & $\begin{array}{l}2 \\
2\end{array}$ \\
\hline 15 & $\begin{array}{l}\mathbf{R} \\
\mathbf{L}\end{array}$ & $\begin{array}{l}18 \text { steady } \\
19 \text { steady }\end{array}$ & $\begin{array}{l}0 \\
1\end{array}$ \\
\hline 16 & $\mathbf{L}$ & 18 steady & 5 \\
\hline 17 & $\mathbf{R}$ & 18 steady & 0 \\
\hline 18 & $\mathbf{R}$ & 19 steady & 4 \\
\hline 19 & $\begin{array}{l}\mathbf{R} \\
\mathbf{L}\end{array}$ & $\begin{array}{l}27 \text { steady } \\
24 \text { steady }\end{array}$ & $\begin{array}{l}7 \\
4\end{array}$ \\
\hline
\end{tabular}

* "Steady" indicates that intra-ocular pressures had not varied by more than $2 \mathrm{~cm} . \mathrm{H} . \mathrm{O}$ in the 10 minutes preceding

the injection of Diamox. " Rilling" indicate that the in tra-ocular pressures had increased or decreased by more than $2 \mathrm{~cm}$ $\mathrm{H}_{2} \mathrm{O}$ in the 10 minutes preceding the injection of Diamox 
Solutions of the sodium salt of Diamox are alkaline, having a $p \mathrm{H}$ of about $9 \cdot 1$, and it was therefore necessary to eliminate the possibility that the intra-ocular pressure effect was due to the injection of an alkaline solution. Intravenous

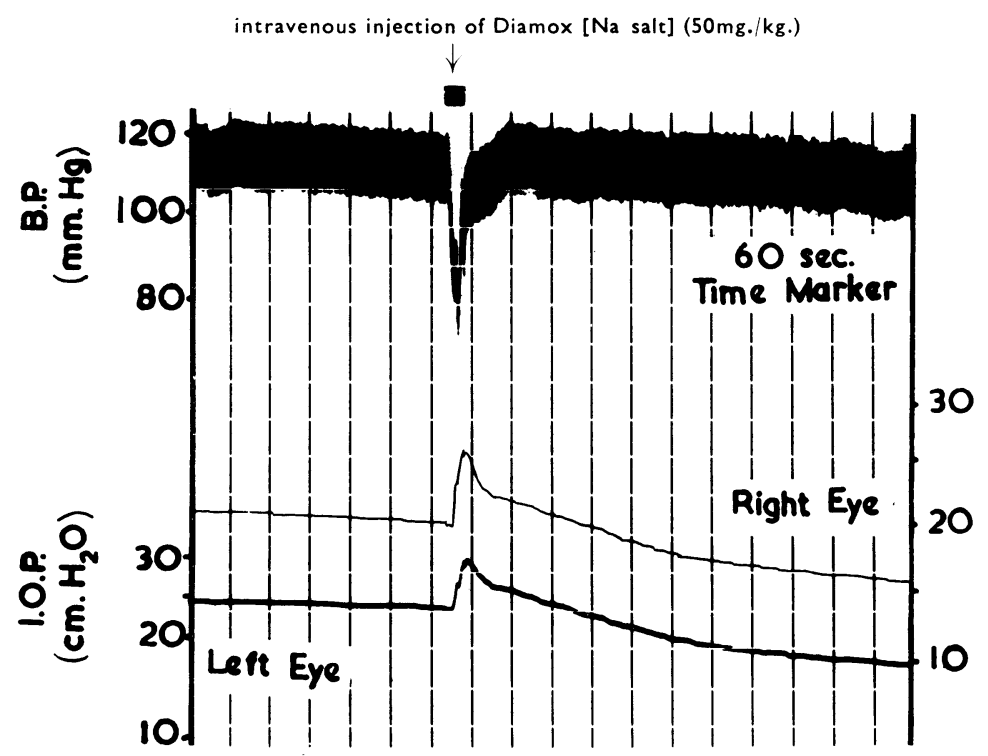

FIG. 1.-Effect of an intravenous injection of 5 per cent. Sodium Diamox Solution $(50 \mathrm{mg} . / \mathrm{kg}$.) on intra-ocular pressure of a rabbit.

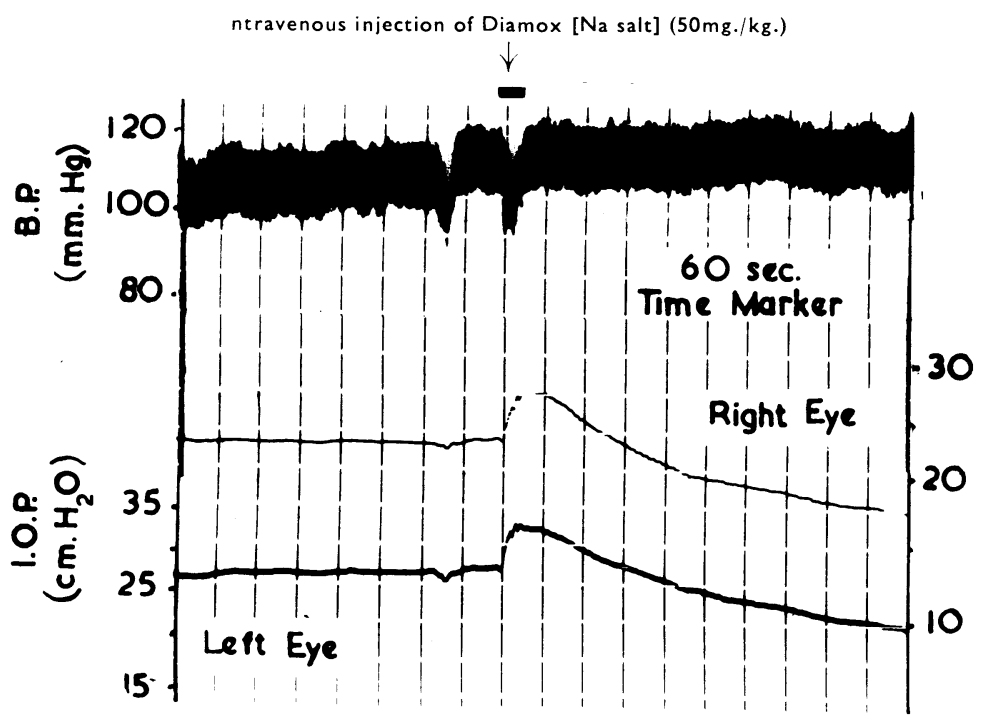

FIG. 2.-Effect of an intravenous injection of 5 per cent. Sodium Diamox Solution $(50 \mathrm{mg} . / \mathrm{kg}$.) on intra-ocular pressure of a rabbit. 


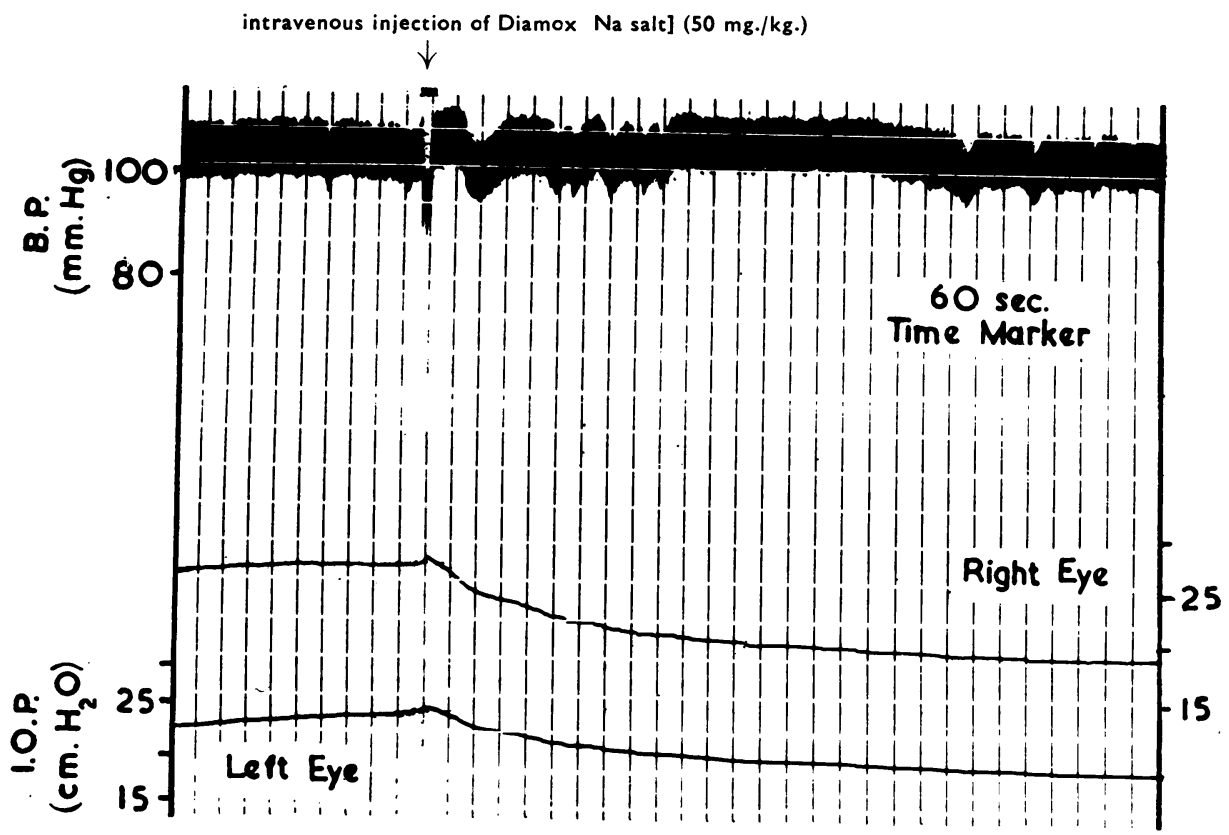

Fig. 3.-Effect of an intravenous injection of 5 per cent. Sodium Diamox Solution $(50 \mathrm{mg} . / \mathrm{kg}$.) on intra-ocular pressure of a rabbit.

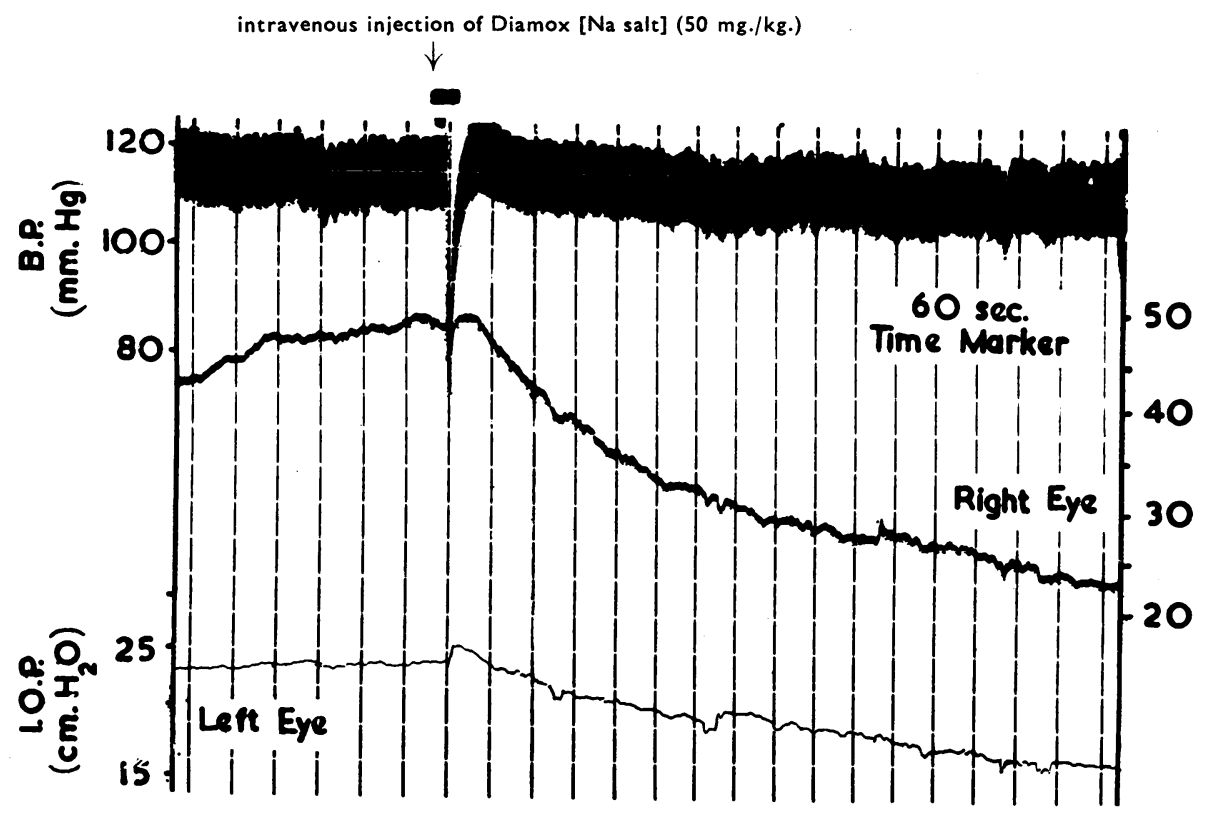

FIG. 4.-Effect of an intravenous injection of 5 per cent. Sodium Diamox Solution ( $50 \mathrm{mg} . / \mathrm{kg}$.) on intra-ocular pressure of a rabbit. 
injections of a sodium hydroxide-glycine buffer, having a $p \mathrm{H}$ of $9 \cdot 1$, were therefore given to ten rabbits, but no effect on the intra-ocular pressure was found Similarly, injections of pyrogen-free water and saline were without effect upon the intra-ocular pressure.

(b) Diamox (5 mg./kg.) Intravenously.-The clinical dosage of Diamox approximates to $5 \mathrm{mg}$. $/ \mathrm{kg}$. and it was therefore of interest to ascertain whether this dosage would reduce the intra-ocular pressure in rabbits.

Method.-The same procedure was followed, except that a 0.5 per cent. solution of sodium Diamox was injected.

Results.--Five rabbits were investigated. The results are given in Table II which shows that there was a small reduction in intra-ocular pressure in four animals. Figs 5 and 6 (opposite) show the effects in two rabbits.

TABLE II

EFFECT OF INTRAVENOUS SODIUM DIAMOX $(5 \mathrm{mg} . / \mathrm{kg}$. ON INTRA-OCULAR PRESSURE OF RABBITS

\begin{tabular}{|c|c|c|c|}
\hline Rabbit & Eye & $\begin{array}{l}\text { Initial Intra-Ocular Pressure } \\
\qquad\left(\mathrm{cm} . \mathrm{H}_{2} \mathrm{O}\right)\end{array}$ & $\begin{array}{l}\text { Fall in Intra-Ocular Pressure } \\
\left(\mathrm{cm} . \mathrm{H}_{2} \mathrm{O}\right) \\
15 \text { min. after Diamox Injection }\end{array}$ \\
\hline A & $\begin{array}{l}\mathrm{R} \\
\mathrm{L}\end{array}$ & $\begin{array}{l}24 \text { steady }{ }^{*} \\
22 \text { steady }\end{array}$ & $\begin{array}{l}5 \\
2\end{array}$ \\
\hline B & $\begin{array}{l}\mathrm{R} \\
\mathrm{L}\end{array}$ & $\begin{array}{l}22 \text { falling* } \\
22 \text { falling }\end{array}$ & $\begin{array}{l}2 \\
1\end{array}$ \\
\hline C & $\begin{array}{l}\mathrm{R} \\
\mathrm{L}\end{array}$ & $\begin{array}{l}23 \text { steady } \\
25 \text { steady }\end{array}$ & $\begin{array}{l}2 \\
2\end{array}$ \\
\hline D & $\begin{array}{l}\mathrm{R} \\
\mathrm{L}\end{array}$ & $\begin{array}{l}17 \text { falling } \\
16 \text { falling }\end{array}$ & $\begin{array}{l}0 \\
0\end{array}$ \\
\hline $\mathrm{E}$ & $\begin{array}{l}\mathrm{R} \\
\mathrm{L}\end{array}$ & $\begin{array}{l}19 \text { steady } \\
19 \text { steady }\end{array}$ & 2 \\
\hline
\end{tabular}

*See note in Table I

\section{(II) Effect of the Intravenous Injection of Sodium Diamox on Intra-Ocular Pressure in Cats}

Method.-Cats weighing $2 \cdot 5-4 \cdot 5 \mathrm{~kg}$. were anaesthetized by the intraperitoneal injection of nembutal in a dosage of $43 \mathrm{mg}$. $/ \mathrm{kg}$. body-weight. Blood pressure and intraocular pressures were measured as described in the experiments on rabbits. The sodium salt of Diamox was injected intravenously as a 5 per cent. solution in a dosage of 50 $\mathrm{mg} . / \mathrm{kg}$.

Results.-Five cats were investigated and a fall in intra-ocular pressure was observed in four (Table III, overleaf). The results for two animals are seen in Figs 7 and 8 (overleaf). In cats, the injection of Diamox caused a transient fall in blood pressure, but, in contrast to rabbits, this was accompanied by a rapid fall in intra-ocular pressure followed by a rise to the initial level. As in rabbits, the slow fall in intra-ocular pressure began very soon after Diamox was injected. 


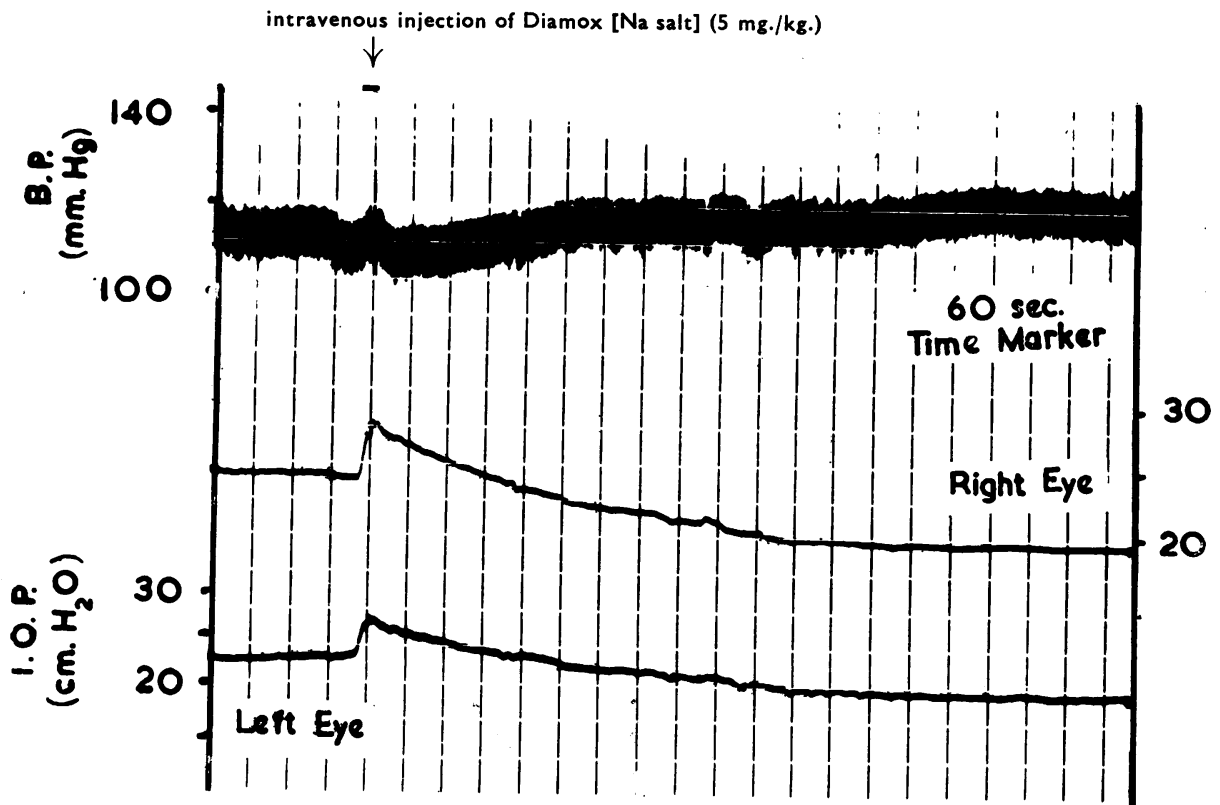

FIG. 5.-Effect of an intravenous injection of 0.5 per cent. Sodium Diamox Solution $(5 \mathrm{mg} . / \mathrm{kg}$.) on intra-ocular pressure of a rabbit.

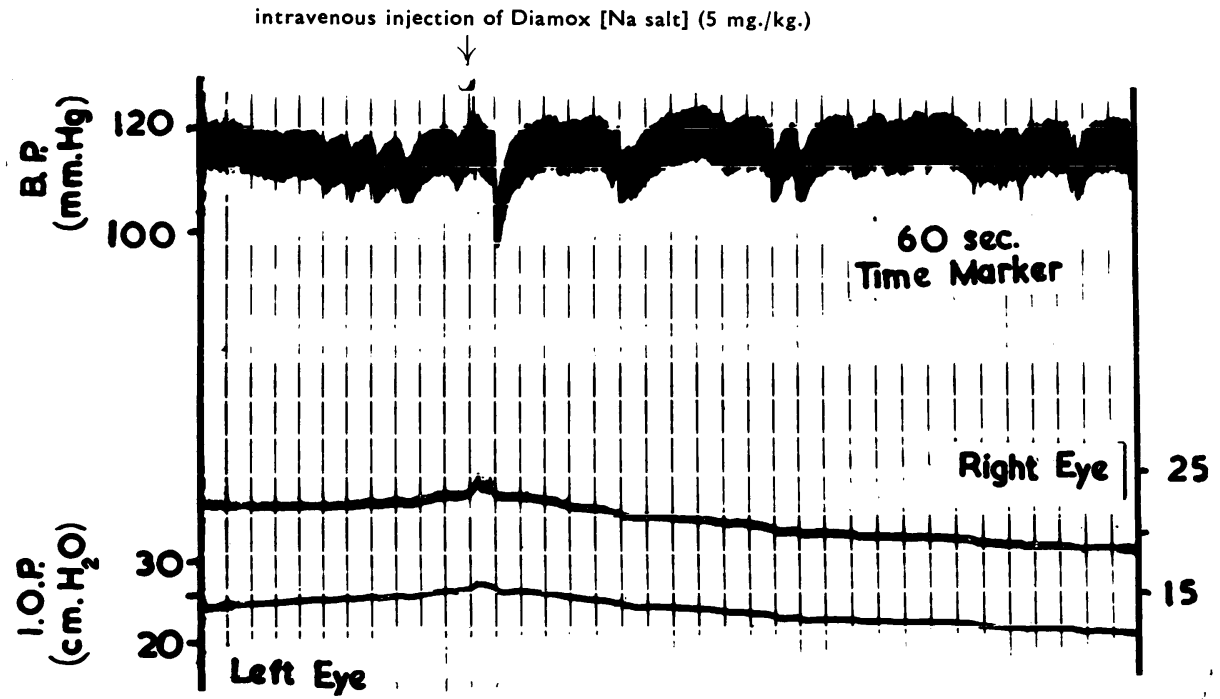

FIG. 6.-Effect of an intravenous injection of 0.5 per cent. Sodium Diamox Solution $(5 \mathrm{mg} . / \mathrm{kg}$.) on intra-ocular pressure of a rabbit.

(III) Effect of Diamox, administered Locally to the Eye, on the InTra-Ocular Pressure in RabBits

It has been suggested by Becker (1955) that Diamox induces a reduction in intra-ocular pressure by inhibiting carbonic anhydrase in the ciliary body and so 
TABLE III

EFFECT OF INTRAVENOUS SODIUM DIAMOX $(50 \mathrm{mg} . / \mathrm{kg}$. ON INTRA-OCULAR PRESSURE OF CATS

\begin{tabular}{|c|c|c|c|}
\hline Cat & Eye & $\begin{array}{l}\text { Initial Intra-Ocular Pressure } \\
\qquad\left(\mathrm{cm} . \mathrm{H}_{2} \mathrm{O}\right)\end{array}$ & $\begin{array}{l}\text { Fall in Intra-Ocular Pressure } \\
\left(\mathrm{cm} . \mathrm{H}_{2} \mathrm{O}\right) \\
15 \text { min. after Diamox Injection }\end{array}$ \\
\hline 1 & $\begin{array}{l}\mathrm{R} \\
\mathrm{L}\end{array}$ & $\begin{array}{l}22 \text { steady * } \\
20 \text { steady * }\end{array}$ & $\begin{array}{l}4 \\
4\end{array}$ \\
\hline 2 & $\begin{array}{l}\mathrm{R} \\
\mathrm{L}\end{array}$ & $\begin{array}{l}13 \text { falling* } \\
12 \text { steady }\end{array}$ & $\begin{array}{l}0 \\
0\end{array}$ \\
\hline 3 & $\begin{array}{l}\mathrm{R} \\
\mathrm{L}\end{array}$ & $\begin{array}{l}21 \text { steady } \\
21 \text { steady }\end{array}$ & $\begin{array}{l}5 \\
5\end{array}$ \\
\hline 4 & $\begin{array}{l}\mathrm{R} \\
\mathrm{L}\end{array}$ & $\begin{array}{l}17 \text { falling } \\
18 \text { falling }\end{array}$ & $\begin{array}{l}0 \\
2\end{array}$ \\
\hline 5 & $\begin{array}{l}\mathrm{R} \\
\mathrm{L}\end{array}$ & $\begin{array}{l}19 \text { steady } \\
23 \text { steady }\end{array}$ & $\begin{array}{l}5 \\
5\end{array}$ \\
\hline
\end{tabular}

decreasing the rate of formation of aqueous humour. In order to examine this possibility the substance was administered locally to one eye only in a series of rabbits. The routes employed were:
(a) subconjunctival injection
(b) injection into the anterior chamber
(c) injection into one carotid artery.

\section{(a) Subconjunctival Injection}

Method.-Intra-ocular pressures and blood pressure were measured as before, and needles were inserted subconjunctivally in both eyes and held in position by clamps. Three solutions were used:

(i) 5 per cent. solution of sodium Diamox

(ii) Solution of sodium Diamox adjusted to $p \mathrm{H} 7.4$ in $0.1 \mathrm{~m}$ phosphate buffer and made isotonic by the addition of sodium chloride. The concentration of sodium Diamox was $2.5 \mathrm{mg} . / \mathrm{ml}$.

(iii) Saturated solution of Diamox in physiological saline.

These solutions were injected subconjunctivally in one eye and a control injection of physiological saline or phosphate buffer was made subconjunctivally in the other eye. 'The volume of solution injected varied from 0.25 to $1.0 \mathrm{ml}$.

Results.-In one rabbit to which the 5 per cent. solution was administered subconjunctivally there was a marked local reaction with chemosis and hyperaemia of the conjunctiva accompanied by a rise in intra-ocular pressure. The buffered solution of sodium Diamox injected subconjunctivally in another rabbit caused only slight local reaction, but there was no reduction of intra-ocular pressure. The saturated solution of Diamox failed to produce any fall in intra-ocular pressure in two rabbits when administered by this route.

\section{(b) Injection into the Anterior Chamber}

Method.-After inserting the needle for measurement of the intra-ocular pressure a second needle $0.25 \mathrm{~mm}$. in diameter, through which the injections were made, 


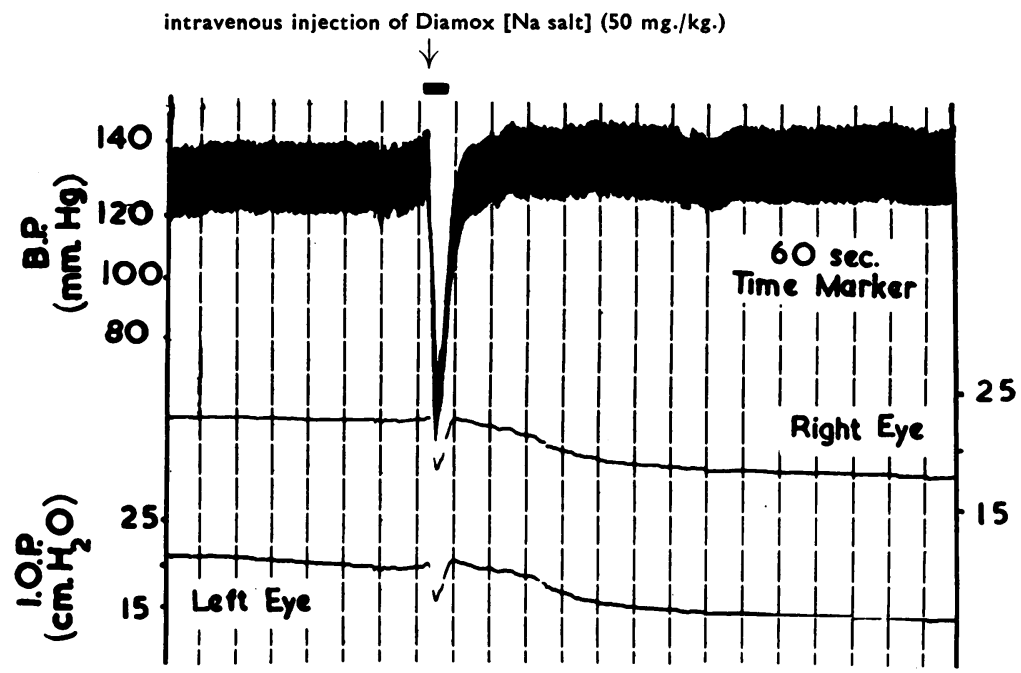

Fig. 7.-Effect of an intravenous injection of a 5 per cent. Sodium Diamox Solution on intra-ocular pressure of a cat.

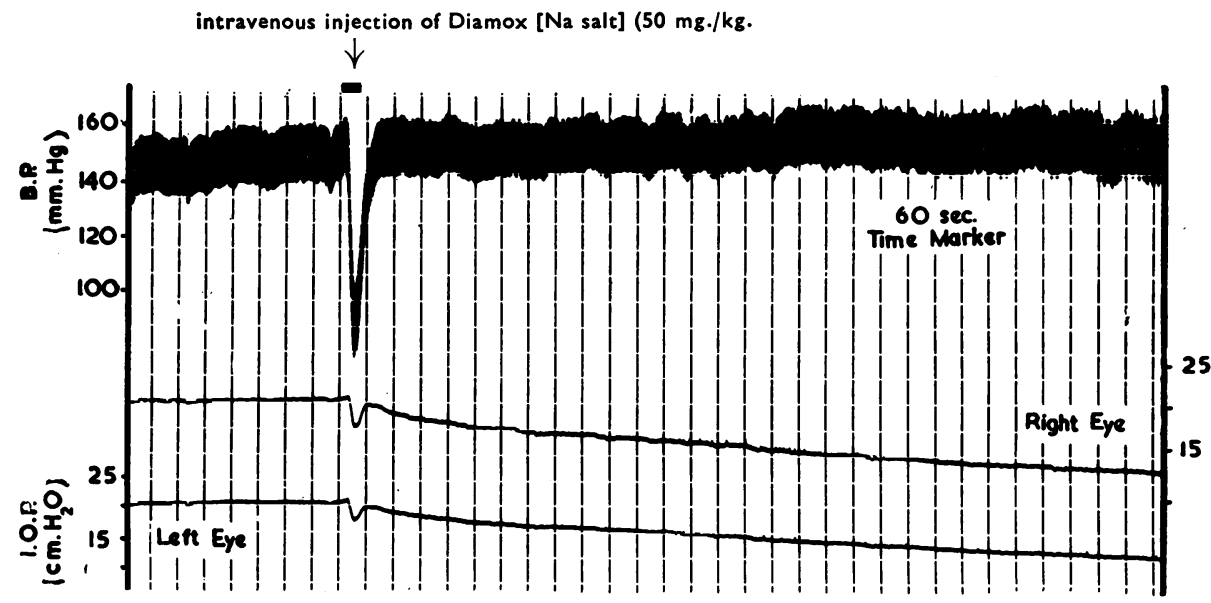

Fig. 8.-Effect of an intravenous injection of a 5 per cent. Sodium Diamox Solution intra-ocular pressure of a cat.

was inserted into the anterior chamber of each eye. At the time of the injection, the intra-ocular pressure of the eye was noted and the manometer reservoir was adjusted to this level and its tap opened so that the injection could be made at a constant pressure. Immediately afterwards the tap to the manometer reservoir was closed and the intra-ocular pressure recording continued. Two solutions were used:

(i) Sodium Diamox solution buffered to $p \mathrm{H} \mathrm{7.4} \mathrm{(as} \mathrm{for} \mathrm{subconjunctival} \mathrm{injection).}$

(ii) Saturated solution of Diamox in physiological saline.

$0.1 \mathrm{ml}$. solution was injected, an equal volume of phosphate buffer or saline being injected into the anterior chamber of the other eye. 
Results.-Administration by this route has been tried on only two rabbits but in neither was there any reduction in intra-ocular pressure.

\section{(c) Injection into the Carotid Artery}

Method.-The carotid artery on one side was exposed and a T-cannula was inserted so that injections could be made directly into the artery. The intra-ocular and blood pressures were recorded as before. A 5 per cent. solution of the sodium salt of Diamox was used, the following volumes and rates of injection being tried:

$0.1 \mathrm{ml}$. in $3 \mathrm{sec} ., 1.0 \mathrm{ml}$. in $5 \mathrm{sec}$., and $1.0 \mathrm{ml}$. in $30 \mathrm{sec}$.

Results.-Five rabbits were used, but in none did a definite reduction in intraocular pressure follow the injection.

\section{(IV) Effect of Injections of Sodium Diamox Solutions on BLOOD Vessels}

The rapid transient fall in blood pressure and the initial rise in intra-ocular pressure after intravenous injections of solutions of sodium Diamox in the rabbit suggested that this substance has a vasodilator action, and the following experiments were carried out to test this hypothesis.

Method.-The apparatus used is illustrated diagrammatically in Fig. 9. Rabbits were anaesthetized with urethane and a four-way cannula, A, was tied into the carotid or

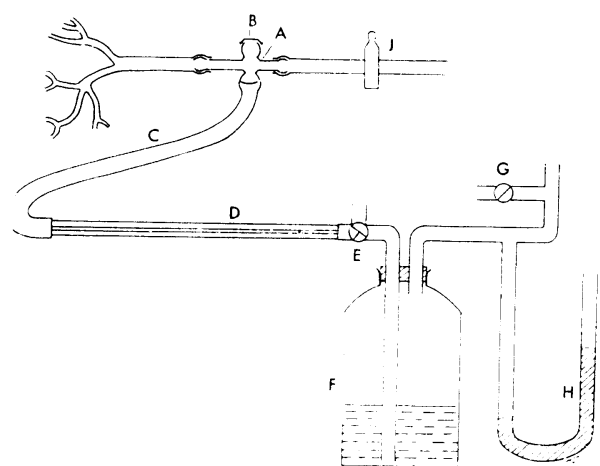

FIG. 9.-Diagram of apparatus for studying effect of Diamox on arterial blood-flow.

measured by a mercury manometer, $\mathrm{H}$. to the cannula by means of a clamp, J. In the "control runs", the air-bubble in the capillary tube was adjusted to a suitable position near the end connected to the flask, F, and its position read off from the metre rule, and the tap, E, was then closed. The pressure in $F$ was raised to the required level and the clamp, $J$, was applied to the artery. On opening the tap, E, saline was driven into the artery and its rate of flow was determined by noting with a stop-watch the time taken for the bubble to reach the other end of the capillary tube; the movement of the bubble was stopped by closing the tap, E, quickly and the exact position at which it stopped was read off from the metre rule. The clamp, J, was immediately removed. In this way, the rate at which saline could be driven through the tissues supplied by the cannulated artery was determined and, knowing the cross-sectional area of the capillary tube, the volume flowing in unit time could be calculated. The cross-sectional area of the capillary tube was determined by injecting known amounts of saline from a micrometer syringe. In the "saline runs", or other substances could be made. cannula was also connected by means of a polythene tube, $\mathrm{C}$, to a capillary tube, $\mathrm{D}$, rule graduated in millimetres. Both $C$ and $\mathrm{D}$ were filled with physiological saline and a small air bubble was introduced into the lary tube was connected through a tap, to a large flask, F, containing saline, the pressure of which could be maintained at rious levels by means of a pump connected to the flask. The pressure was regulated by means of the tap, G, and was

femoral artery. One inlet to the cannula

e


$0.5 \mathrm{ml}$. physiological saline was injected through the rubber cap, B, and 5 seconds later the clamp, J, was applied, the tap, E, opened, and the movement of the bubble in the capillary tube observed as before. The same procedure was followed for runs with Diamox and other substances, the volume injected being $0.5 \mathrm{ml}$. A 5 per cent. solution of the sodium salt of Diamox was used.

Results.-The results of five experiments are summarized in Table IV, which shows that, after injecting a solution of the sodium salt of Diamox, the saline flowed more rapidly along the capillary tube than after injections of physiological saline. This increase does not appear to be due to the alkalinity of solutions of sodium Diamox since a faster rate was not observed after injections of a sodium hydroxide-glycine buffer of $p \mathrm{H} 9 \cdot 1$. The difference between the average rates for the "saline runs" and the "Diamox runs" has been tested statistically for Rabbits 2, 3, 4, and 5, and the differences are significant. These results suggest that the sodium Diamox solution had a vasodilator action, but this effect was not as great as that caused by the injection of $2 \cdot 5 \mu \mathrm{g}$. acetyl choline. The effect was transient, since "control" and "saline runs" carried out 3 or 4 minutes after a "Diamox run" did not show increased rates of flow of saline.

TABLE IV

EFFECT OF DIAMOX ON RATES OF FLOW THROUGH ARTERIES IN RABBITS

\begin{tabular}{|c|c|c|c|c|c|c|c|}
\hline \multirow[b]{2}{*}{ Rabbit } & \multirow[b]{2}{*}{ Artery } & \multirow{2}{*}{$\begin{array}{c}\text { Pressure } \\
\text { in } \\
\text { Flask F } \\
(\mathrm{mm} . \mathbf{H g})\end{array}$} & \multicolumn{5}{|c|}{$\begin{array}{l}\text { Rate of Flow of Saline (cu.mm./sec.) } \\
\text { Mean } \pm \text { S.E. (No. of Observations in brackets) }\end{array}$} \\
\hline & & & Control & Saline & Diamox & $\begin{array}{c}\text { NaOH- } \\
\text { Glycine } \\
\text { Buffer } \\
(p \mathbf{H ~ 9} \cdot 1)\end{array}$ & $\begin{array}{l}2 \cdot 5 \gamma \\
\text { Acetyl } \\
\text { Choline }\end{array}$ \\
\hline 1 & Carotid & 110 & - & $48 \cdot 4$ (3) & $70 \cdot 2(2)$ & 一 & - \\
\hline 2 & Femoral & 80 & $\begin{aligned} & 61 \cdot 5 \\
\pm & 1 \cdot 41(12)\end{aligned}$ & $\begin{aligned} & 56 \cdot 6 \\
\pm & 1 \cdot 58(6)\end{aligned}$ & $\begin{aligned} & 77 \cdot 3 \\
+ & 1 \cdot 33(6)\end{aligned}$ & $\begin{aligned} & 56 \cdot 6 \\
\pm & 1 \cdot 41^{(6)}\end{aligned}$ & - \\
\hline 3 & Carotid & 150 & $\begin{aligned} & 62 \cdot 5 \\
\pm & 1 \cdot 61(5)\end{aligned}$ & $\begin{array}{r}63 \cdot 3 \\
\pm 2 \cdot 35(6)\end{array}$ & $\begin{aligned} & 75 \cdot 8 \\
\pm & 8 \cdot 08\end{aligned}$ & - & $\begin{array}{l}111 \cdot 4 \\
(2)\end{array}$ \\
\hline 4 & Carotid & 80 & $\begin{aligned} & 64 \cdot 9 \\
\pm & 1 \cdot 50(5)\end{aligned}$ & $\begin{aligned} & 65 \cdot 7 \\
\pm & 1 \cdot 08(5)\end{aligned}$ & $\begin{aligned} & 76 \cdot 5 \\
\pm & 1 \cdot 50(5)\end{aligned}$ & $\begin{array}{r}64 \cdot 9 \\
+1 \cdot 50(5) \\
\end{array}$ & $\begin{array}{l}100 \cdot 62 \\
\pm 1 \cdot 58(5) \\
\end{array}$ \\
\hline 5 & Carotid & 40 & $\begin{array}{r}94 \cdot 9 \\
\pm 11 \cdot 23(10)\end{array}$ & $\begin{aligned} & 79 \cdot 3 \\
\pm & 6 \cdot 42(11)\end{aligned}$ & $\begin{array}{r}105 \cdot 7 \\
+9 \cdot 03(4)\end{array}$ & - & - \\
\hline
\end{tabular}

\section{Discussion}

These experiments show that intravenous injections of the sodium salt of Diamox often cause a small reduction in intra-ocular pressure in normal eyes of anaesthetized rabbits and cats. In eyes having intra-ocular pressures above the physiological level, the effect was sometimes greater than in normal eyes.

The initial rise in intra-ocular pressure and fall in blood pressure, which were observed in some rabbits, can probably be attributed to a transient vasodilator action of the sodium Diamox solution. Blood flow estimations confirmed that sodium Diamox can cause vasodilatation, which recovers within a few minutes.

Apart from the initial temporary rise, it was tound that the intra-ocular 
pressure began to decrease very soon after the intravenous injection of sodium Diamox; in all experiments showing a reduction in pressure, this was evident in 3 to 4 minutes, and in some the drop could be observed after 60 to 120 seconds. This finding is in agreement with the results of Becker (1955) who was able to demonstrate by tonometry that a reduction in ocular tension was evident 5 to 10 minutes after the intravenous injection of Diamox.

The rapidity of action of this substance on the intra-ocular pressure has been regarded as evidence in favour of the hypothesis that the intra-ocular pressure reduction results from a local effect upon the eye rather than from a systemic effect, but, in the present state of our knowledge, the rapidity of action of Diamox should not be accepted as proof of a local effect upon the eye.

The failure to demonstrate a reduction of ocular tension after subconjunctival injection of solutions of sodium Diamox has been recorded by Grant and Trotter (1954) and by Becker and Demorest (1954) and our results are in agreement with this finding. Moreover, neither with injections into the anterior chamber nor into the carotid artery was a reduction in intra-ocular pressure observed.

It is of interest to note that Green, Bocher, Calnan, and Leopold (1955) reported that the subconjunctival administration of $10 \mathrm{mg}$. Diamox in rabbits caused complete inhibition of carbonic anhydrase in the iris and ciliary body within 15 minutes. Despite this, our experiments showed that local administration of Diamox did not lower the intra-ocular pressure, and it must be concluded therefore that no evidence has been provided to support the view that a local action upon the eye is responsible for the reduction of intra-ocular pressure.

\section{SUMMARY}

Intravenous injections of sodium Diamox in doses of 5 and $50 \mathrm{mg} . / \mathrm{kg}$. reduced the normal intra-ocular pressure in anaesthetized rabbits and cats.

Subconjunctival injections, intra-carotid injections, and injections into the anterior chamber did not reduce the intra-ocular pressure.

Blood-flow estimations showed that sodium Diamox can cause a transient vasodilatation.

We are grateful to Lederle Laboratories for supplying the Diamox used in these experiments.

\section{REFERENCES}

BeCKer, B. (1954). Amer. J. Ophthal., 37, 13. (1955). Ibid., 39, No. 2, pt. 2, p. 177.

- and DEMOREST, B. (1954). Unpublished observations quoted by Becker (1955).

Breinin, G. M., and Görtz, H. (1954). Arch. Ophthal. (Chicago), 52, 333.

Davson, H., and PuRvis, C. (1950). British Journal of Ophthalmology, 34, 351.

Grant, W. M., and TrotTer, R. R. (1954). Arch. Ophthal. (Chicago), 51, 735.

Green, H., Bocher, C. A., CAlnAN, A. F., and LeOPOLD, I. H. (1955). Ibid., 53, 463.

KLEINERT, H. (1954). Klin. Mbl. Augenheilk., 125, 271.

Perkins, E. S. (1955). Trans. ophthal. Soc. U.K., 75. (In the press). 